\title{
THE REPRESENTATION OF SPUNK IN THE SHORT STORY ENTITLED SPUNK BY ZORA NEALE HURSTON
}

\author{
Ratna Asmarani \\ English Department, Faculty of Humanities, \\ Diponegoro University, Semarang, Indonesia \\ ratna_asmarani@yahoo.com
}

\begin{abstract}
The aim of this paper is to analyze the representation of spunk (courage) in Zora Neale Hurston's short story entitled Spunk. The focus is on the three protagonists, two males and one female who are involved in love relationship. To support the analysis, the concepts of courage is borrowed. The meaning, types, and characteristics of courage are useful to analyze the representation of spunk. The methods of analysis used are a combination of library research method with its close reading, qualitative method focusing on the contextual method for literary analysis. The result shows that each protagonist has unique type of courage whether the courage hiding the cowardice, the courage emerging after conquering fear even though having to face deadly risk, or the courage to decide done by the female considered as the dependent second sex. Thus, courage may take many forms that need close analysis to reveal each form.
\end{abstract}

Keywords: spunk; courage; contextual literary analysis

\section{Introduction}

The short story entitled Spunk is written by Zora Neale Hurston (1891-1960), a female African-American writer. It tells about the male protagonist called Spunk Banks, a big fearless man, who arrogantly took Joe Kanty's wife, called Lena Kanty, as his own wife. Lena herself preferred Spunk to her husband who was weak and timid. Provoked by the other men in the pub, the miserable Joe, armed with a big razor, went alone looking for Spunk who had a big gun. Easily Spunk shot Joe dead under the excuse that Joe sneaked behind him and threatened his life. However, after Joe's death Spunk began to sense that Joe haunted him in the form of a black bobcat and he felt nervous about that. When Spunk fell over the circle saw in the saw mill where he worked, he told the others, on his dying breath that the late Joe pushed him from behind.

In order to find a gap, a focus in the short story that has not been done before, a previous study was done. The results are as follows. Cheryl Y. Williams (1987) in her article "Zora Neale Hurston and the emergence of self" talks about all Hurston's works including "Spunk" focusing on the emergence of self. David G. Hale's article (1993) entitled "Hurston's "Spunk" and Hamlet" compares the short story with the famous drama in which he says: "a man (Spunk/Claudius) desires the wife (Lena Kanty/Gertrude) of another (Joe Kanty/King Hamlet), kills him, and arranges to marry her." Dan Olson (2013) in "African-American dialect the heart of Penumbra's 'Spunk" talks about the Black Southern dialect in the short story. Heather Gibson (2016) in "Spunk and the Harlem Literati' Captures Words, Spirit of Zora Neale Hurston" talks about the plan to adapt the short story into theater performance. Elizabeth Slaine's article (2018) entitled "Mystery, Tension, and the Supernatural in Zora Neale Hurston's Spunk" focuses on the supernatural atmosphere in the short story.

Based on the previous study it can be seen that there is no discussion on the representation of spunk in the short story. The focus on the representation of spunk 
will make clear the kinds of spunk in the short story entitled "Spunk". To discuss the representation of spunk, several concepts need reviewing. The word "spunk", which becomes the title of Hurston's short story and also the first name of one of its male protagonists, according to On-line Cambridge English Dictionary is an old-fashioned and informal word meaning "courage and determination".

Bearing in mind that the basic meaning of the word spunk is courage, several concepts concerning the word "courage" will be briefly reviewed. Rabieh states that courageous people are those who "act boldly in the face of uncertainty or who risk incurring what is terrible for themselves" (2006: 73). From the psychological perspective, Yang, Milliren and Blagen give a simple definition of courage as "a willingness for risk taking and movement forward in the presence of difficulties" (2010: 4).

According to Kidder, the term "courage" is commonly divided into two meaning; namely physical courage and moral courage (2006: 9). Still according to Kidder, the word "courage" usually refers to "physical courage" deriving from the Latin word "cor" which means "heart" (2006: 25). Kidder differentiates physical courage from moral courage as follows. Physical courage "may be driven by a sense of honor ... shaped by a concern over reputation ... often bolstered with cheers of encouragement and team spirit" (2006: 9-10) while moral courage is "a commitment to moral principles, an awareness of the danger involved in supporting those principles, and a willing endurance of that danger" (2006: 7) in which "Acts of moral courage carry with them risks of humiliation, ridicule, and contempt" (2006: 10).

In general courage has the following characteristics. According to Yang, Milliren, and Blagen:
Courage can be a virtue, a state of mind, an attitude, an emotion, a force, or an action ... manifested in overt overcoming or in covert endurance, in confrontation or in persevering and suffering (2010: 34).

Yang, Milliren, and Blagen also add that "Courage is a response to danger, despair, or fear" (2010: 5), however, "courage does not equate to fearlessness and it does not make fear disappear" (2010:10). They emphasize that courage can take many different manifestations and a courageous person is not a fearless one.

Meanwhile, Milner also gives other characteristics of courage. According to Milner "Courage can be quiet or vocal" (2002: 196). He also says that men are supposed to have "Courage, manliness, manly virtue" (2002: 233), emphasizing that "for men to be men they must be courageous; otherwise they are like women, only lower" (2002: 234). Thus, if a man does not have courage, then he is considered lower that a woman. Greenberg (2012) in her internet article entitled "The Six Attributes of Courage" proposes 6 characteristics of courageous actions; namely, "1. Feeling Fear Yet Choosing to Act, 2. Following Your Heart, 3. Persevering in the Face of Adversity, 4. Standing Up For What Is Right, 5. Expanding Your Horizons; Letting Go of the Familiar, and 6) Facing Suffering With Dignity or Faith". Greenberg's opinion covers the ideas of the previous thinkers of the concept of courage.

Based on the summary of the short story entitled Spunk written by Zora Neale Hurston, the previous study, and the concepts concerning "courage", the focus of analysis is about the spunk or courage in the short story represented by the three protagonists; namely, Joe Kanty, Lena Kanty, and Spunk Banks. Each character is analyzed to discover the unique form of courage that each of them represents. 


\section{Methods of Research}

To analyze Hurston's Spunk, several methods are combined. The library research method with its close reading is used to collect the data from the short story and from the supporting concepts whether from printed or electronic sources. The qualitative method is used to analyze the data while the contextual method (Behrendt, 2008) is used since the analysis is a combination of intrinsic and extrinsic elements. The intrinsic elements mainly focus on the characters and conflicts, especially concerning the three protagonists already mentioned before, while the extrinsic elements mainly about the concepts concerning the term courage that has been reviewed briefly in the previous section.

\section{Findings and Discussions}

Courage is unique because it has no single form. Intimidating appearance does not always represent courage. Fearful person does not mean of having no courage at all. Courage also does not belong to the males only. These complicated representations of courage are portrayed in the characters of Joe Kanty, Lena Kanty, and Spunk Banks.

\section{Spunk Banks}

Spunk Banks is the intruder in the marital relationship of Joe Kanty and Lena Kanty. Cockily he takes Lena as his own. His intimidating physical appearance "A giant of a brown skinned man" (Hurston, 1995: 26) silences Joe's protest. He is also famous for being a fearless person as stated by other males in the pub: "he ain't skeered of nothing" (Hurston, 1995: 26). It is implied that other people, if not afraid of him, are reluctant to find problem with him.

$\mathrm{He}$ is also described by the other men in the pub as a bold person because he shows no fear toward the deathly tools at the saw mil; that is why, the other men do not feel surprised when he claims Lena as his wife even though Lena still has a husband:
He rides that log down at saw-mill jus' like he struts 'round wid another man's wife-jus' don't give a kitty. When Tes' Miller got cut to giblets on that circle-saw, Spunk steps right up and starts ridin'. The rest of us was skeered to go near it (Hurston, 1995: 26).

At this point, Spunk represents physical courage because his courage is supported by his physical appearance. This courage is used to build a personal reputation for his own sake.

The constructed image of a fearless person gives Spunk the opportunity to act as he wants without any significant defiance from others, such as in the case of claiming Lena as his own. The words from one of the men in the pub clearly indicate Spunks's behavior: "He'd go after anything he wanted the same way" (Hurston, 1995: 28). Spunk is excused to do anything he wants because nobody want to interfere with such a person.

The label as a fearless person is also supported by his always taking a big gun with him. Nobody wants to have a problem with him and his gun. Moreover, he uses his big gun freely, as in the case with Joe. Confronting the weak Joe which is armed with a big razor only, Spunk freely uses his gun to shoot death Joe, instead of just shooting him at non-fatal body parts:

"Well," Spunk announced calmly, "J oe come out there wid a meatax an' made me kill him."

He sent Lena home and led the men back to Joe-Joe crumpled and limp with his right hand still clutching his razor.

"See mah back? Mah cloes cut clear through. He sneaked up an' tried to kill me from the back, but Ah got him, an' got him good, first shot," Spunk said.

"Take him up an" plant him in 'Stoney lonesome," ' Spunk said 
in a careless voice. "Ah didn't wanna shoot him but he made me do it. He's a dirty coward, jumpin' on a man from behind." (Hurston, 1995: 29).

His excuse, which releases him from jail is that it is just a self-defense action in response to Joe's sneaking behind him with a life-threatening weapon.

Since nobody witnesses the bloody event, it is just Spunk's words that describe Joe as a coward, sneaking from behind. Thus, in killing Joe, Spunk also constructs an image that lowers Joe's self-esteem. At this point, Spunk's courage is under question. If he is a truly courageous person, with his big muscular body without firing his gun he can defeat the weak Joe easily, even though Joe has a big razor. Hitting Joe with his gun will end the duel, if it is a real duel. It means that actually Spunk wants to get rid of Joe, Lena's legal husband, forever and he gets a chance to do that. Joe's death makes him able to own Lena without raising many gossips anymore. Spunk has secured his possession of Lena.

Spunk's reputation of being a fearless person is further questioned. After the death of Joe, Spunk, the fearless giant, becomes hallucinated. He says that he sees a big black bobcat that is not afraid of his gun, as can be seen from the following words of a man in the pub:

"a big black bob-cat ... he says it stood right still an' looked him in the eye, an' howled right at him ... got Spunk so nervoused up he couldn't shoot. But Spunk says twasn't no bob-cat nohow. He says it was Joe done sneaked back from Hell!" ... (Hurston, 1995: 30).

This event shows Spunk's cowardice. Armed by a big gun against a much smaller man with a razor in the broad day light, Spunk is so brave; however, still armed with a big gun facing, according to him, a howling big black bob-cat in the dark night, his courage leaves him with no trace at all. Actually, Spunk is haunted by his own guilt of mercilessly killing the weak Joe but his superstitious mind blames it on Joe. Nobody sees the bobcat, so this time it is also Spunk's words blaming the late Joe. In other words, to construct his bravery and to hide his cowardice, Spunk always puts the blame on the deceased Joe.

Spunk's hallucination is getting worse. The same man in the pub who works in the same saw-mill with Spunk tells the others in the pub about an almost fatal incident in the saw-mill. Spunk claims that the big saw is out of order and almost hurts him fatally; however, when the technician proves that nothing is wrong with the big saw Spunk firmly declares that somebody pushes him even though nobody is around him:

"Spunk wuz cussin' a blue streak to-day 'cause he 'lowed dat saw wuz wobblin'-almos' got 'im once. The machinist come, looked it over an' said it wuz alright. Spunk musta been leanin' $t^{\prime}$ wards it some. Den he claimed somebody pushed 'im but 'twant nobody close to 'im. Ah wuz glad when knockin' off time come. I'm skeered of dat man when he gits hot. $\mathrm{He}^{\prime} \mathrm{d}$ beat you full of button holes as quick as he's look etcher." (Hurston, 1995: 31).

Spunk's attitude makes the man who tells the story afraid. The man's fear is understandable. A hallucinated giant is a fearful sight.

Spunk still feels sure that the late Joe keeps wanting to take revenge on him under the disguise of a black bob-cat. This can be seen when he is dying after he falls on a big saw. The man in the pub who witnesses the accident reports Spunk's last words: "the dirty hound pushed me in the back ... the dirty sneak shoved me ... he didn't dare come to mah face ... Ah felt him shove me" (Hurston, 1995: 31). The hallucinated Spunk still accuses the late 
Joe of sneaking behind him to harm him. This event indicates several things about Spunk. First, his courage is just physical. He is fierce to the person who is obviously not his match, like the weak Joe. He brags his action to Joe to get a reputation. However, Spunk is a superstitiously coward person. He hides his cowardice behind his blaming that the late Joe mercilessly haunts him in the form of a black bob-cat intending to take revenge. Since nobody sees a bob-cat, thus it is just Spunk's hallucination. Thus, Spunk is just a superficially courageous person.

\section{Joe Kanty}

Joe Kanty, or Joe, is the husband whose wife, Lena Kanty, is claimed by Spunk Banks. Joe's appearance is the opposite of Spunk's. He has an insignificant appearance: "A roundshouldered figure in overalls much too large" (Hurston, 1995: 26). He tries not to attract the attention of a group of men in the pub because he does not want to converse with them. He is aware that he becomes the object of jokes after Spunk takes his wife and he cannot defend her. His timid reaction to Spunk's action is described as follows by the man in the pub: “'Didn't he meet Spunk an' Lena face to face one day las' week an' mumble sumthin' to Spunk 'bout lettin' his wife alone?" (Hurston, 1995: 28). The men underestimate him because he does not dare to act manly.

The men in the pub also provoke Joe about Lena Kanty and Spunk Banks that have just passed the pub:

"Say, Joe, how's everything up yo' way? How's yo' wife?"

"She jus" passed heah a few minutes ago goin' theta way," with a wave of his hand in the direction of the woods (Hurston, 1995: 26).

Actually Joe feels so miserable but he has nobody to talk about it because other men in the pub clearly underestimate him. This can be seen in his distancing himself from the other men in the pub: "He stood there silent for a long moment staring blankly, with his Adam's apple twitching nervously up and down his throat" (Hurston, 1995: 27). He is fully aware that he is a loser. His self-esteem is trampled down by Spunk.

Joe Kanty's misery is added by Lena's attitude. Lena prefers to follow Spunk than returning to Joe. The men in the pub talk about the occasion when Joe is face to face with Lena and Spunk:

"But didn't he do nothin' to stop her?"

"Nope, not a frazzin' thing-jus' stood there. Spunk took Lena's arm and walked off jus' like nothin' happened and he stood there gazin' after them till they was outa sight. Now you know a woman don't want no man like that ..." (Hurston, 1995: 29).

The men do not blame Lena's action because they think that Joe does not act like a man. They even bet that Joe will never dare to do anything physically against Spunk.

However, although Joe is small and timid finally he cannot help but fight back his trampled self-esteem although he knows the consequence of fighting against the giant Spunk. The men's derision triggers his intention to face the intimidating Spunk.

“Well, Ah'm goin' after her today. Ah'm goin' an' fetch her back. Spunk's done gone too far."

He reached deep down into his trouser pocket and drew out a hollow ground razor, large and shiny, and passed his moistened thumb back and forth over the edge. "Talkin' like a man, Joe. Course that's yo' fambly affairs, but Ah like to see grit in anybody."

Joe Kanty laid down a nickel and stumbled out into the street (Hurston, 1995: 27). 
No men in the pub believe that Joe has the courage to face Spunk, as can be seen from the underestimating words of one of the men: 'I'm jus' waitin' to see what he's goin' to say when he gits back" (Hurston, 1995: 29). They are sure the weak and small Joe will not have enough courage to challenge the gigantic Spunk who always bring a big gun with him. They are all wrong.

It turns out that Joe has enough courage to overcome his fear of Spunk, although he has to die for that, shot by Spunk. The words of one of the men in the pub supports the statement: " "nother thing Joe wuz skeered of Spunk, skeered plumb stiif! But he went jes the same. It took him a long time to get his nerve up" (Hurston, 1995: 30). Although nobody sees the fighting and Spunk tells the men about Joe's cowardice of sneaking from behind, Joe's action is a courageous one. After the death of Joe in an imbalanced fight, one of the men in the pub states: "Know what Ah think? Joe wuz a braver man than Spunk" (Hurston, 1995: 30).

Joe's action meets Greenberg's attributions to courage. Although he is afraid, he finally can overcome his fear and acts properly based on his conscience. Joe's action can also be classified as a moral courage according to Kidder because although he is fully aware of the dangerous risks he still does it because it is the right thing to do as a man and a husband. Joe's courage is a quiet one, according to Milner, not a vocal one as shown by Spunk who talks too much and arrogantly.

\section{Lena Kanty}

Lena Kanty, or Lena, is the legal wife of Joe Kanty. She has the courage to leave Joe for Spunk. The men in the pub think that Lena leaves Joe because Joe is timid and insignificant "a woman don't want no man like that ..." (Hurston, 1995: 29). Spunk is the opposite of Joe. Spunk is so manly and dominating. He acts like a real man who wants to make his woman happy and proud of him: "Then Spunk reaches out an' takes hold of her arm an' says: 'Lena, youse mine. From now on Ah works for you an' fights for you ..." (Hurston, 1995: 28).

Actually Lena willingly follows Spunk because she loves him. This can be seen in the following quotation: "Lena looked up at him with her eyes so full of love that they wuz runnin' over an' Spunk seen it an' Joe seen it too" (Hurston, 1995: 28). Lena is not shy to show what she feels for Spunk even though there are other people in the pub. She is true to her feeling. She does not want to hide it. Thus, it is love that stimulates Lena's courage to act against the norm; that is, leaving a legal husband for another man. Lena's courage is in the form of being honest to her own feeling.

Lena's courage can also be seen in another occasion. Even though she loves Spunk, she does not obey all Spunk's orders. This can be seen when Spunk orders her to leave her house: "Go home an' git yo' things together!'. 'Thass mah house,' Lena speaks up. 'Papa gimme that"' (Hurston, 1995: 28). Lena is courageous enough to express her opinion to the intimidating Spunk. She is not blinded by her love to Spunk. As a woman Lena has the courage to choose and to decide.

Lena's courage can overcome Spunk's fierceness. After she firmly refuses Spunk's order to leave her own house in order to move to Spunk's house, Spunk calms down: "'doan give up whut's yours, but when yuose inside don't forget youse mine, an' let no other man git outa his place wid you!"' (Hurston, 1995: 28). The fearless Spunk does not dare to force Lena to follow his every word because he does not want to lose Lena. The words of one of the men in the pub exactly voice Spunk's feeling to Lena: "Spunk's cracy 'bout Lena. He don't want folks to keep on talkin' 'bout her-thass reason he's rushin' 
so" (Hurston, 1995: 30). Lena, without any force, silently has an undeniable power over the fearless Spunk. Spunk is under Lena's control, not the other way round.

\section{Conclusion}

Spunk Banks, or Spunk, is the representation of physical courage that is superficial but vocal. He builds his reputation as a fearless person. His physical appearance and his big gun support his intimidating aura. However, deep down he is a coward who believes in superstition. Joe Kanty, behind his timid appearance is a courageous person after he is able to put aside his fear. He represents a moral courage. Although he knows that he has to face a risky consequence, he decides to do what he thinks he must finally do. Lena Kanty is also a courageous person. As a woman madly in love with another man, she dares to leave her husband. However, she also dares to contradict her intimidating lover's order to keep what she considers as her right.

From the main points summarized above, it can be concluded that spunk or courage does not have one facet only. Courage cannot be detected easily. Physical courage can be seen clearly, however since it tends to be superficial, it easily evaporates. On the other side, moral courage may develop slower but it is stronger since it has solid base and may have to face personal fear first. Courage also does not belong to the males only. Female may show courage too, although it may take different form. It may be the courage to be true to the personal feeling whatever the consequences in realizing it.

\section{References}

Behrendt, Stephen C. (2008). "Contextual Analysis". (http://www.unl.edu/english/sbe hrendt/StudyQuestions/Contextu alAnalysis.html) diakses 17 February 17, 2014)
Cambridge English Dictionary.

"Spunk".

(https://dictionary.cambridge.or

$\mathrm{g} /$ dictionary/english/spunk

accessed June 14, 2018)

Gibson, Heather. (2016). "Spunk and the Harlem Literati' Captures Words, Spirit of Zora Neale Hurston" (https://today.ucf.edu/spunkand-the-harlem-literaticaptures-words-spirit-of-zoraneale-hurston/ accessed January 8,2019 )

Greenberg, Melanie. (2012). "The Six Attributes of Courage". (https://www.psychologytoday. $\mathrm{com} / \mathrm{us} / \mathrm{blog} /$ the-mindful-selfexpress/201208/the-sixattributes-courage accessed June 9, 2018).

Hale, David G. 1993. "Hurston's "Spunk" and Hamlet"

(https://www.questia.com/librar y/journal/1G1-

14336936/hurston-s-spunk-andhamlet accessed January 8, 2019)

Hurston, Zora Neale. (1995). The Complete Stories. New York: Harper Collins Publishers

Kidder, Rushworth. (2006). Moral Courage. New York: HarperCollins Publishers Inc.

Miller, William Ian. (2002). The Mystery of Courage. Cambridge: Harvard University Press

Olson, Dan. (2013). "AfricanAmerican dialect the heart of Penumbra's 'Spunk"' (https://www.mprnews.org/stor y/2013/04/05/arts/minnesotasounds-and-voices-zora-nealehurston-dialects accessed January 8, 2019)

Rabieh, Linda R. (2006). Plato and the Virtue of Courage. Baltimore: The Johns Hopkins University Press. 
Slaine, Elizabeth. (2018). "Mystery, Tension, and the Supernatural in

Zora Neale Hurston's Spunk" (https://betterlesson.com/lesson/53 5978/mystery-tension-and-thesupernatural-in-zora-neale-hurstons-spunk accessed January 8, 2019)

Yang, Julia; Milliren, Alan; and Blagen, Mark. (2010). The Psychology of Courage. An Adlerian Handbook for Healthy Social Living. New York: Routledge, Taylor \& Francis Group.
Williams, Cheryl Y. (1987). “Zora

Neale Hurston and the emergence of self". Honors Thesis in Department of English University of Richmond, Virginia

(https://scholarship.richmond.edu/cgi/view content.cgi article $=1788 \&$ context $=\mathrm{h}$ onors-thes accessed January 8, 2019) 